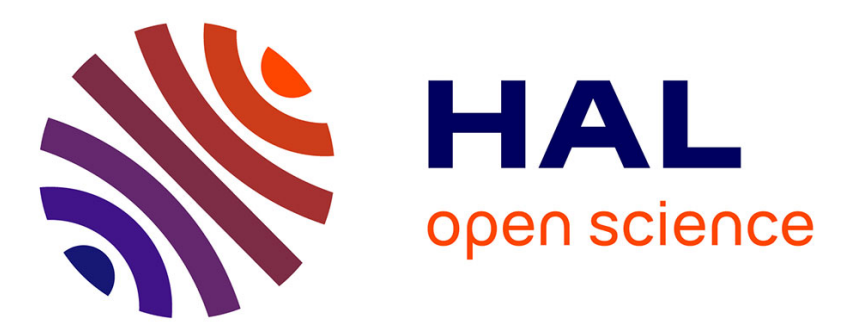

\title{
Modelling anhydrous weight loss of wood chips during torrefaction in a pilot kiln
}

Vincent Repellin, Alexandre Govin, Mathieu Rolland, René Guyonnet

\section{To cite this version:}

Vincent Repellin, Alexandre Govin, Mathieu Rolland, René Guyonnet. Modelling anhydrous weight loss of wood chips during torrefaction in a pilot kiln. Biomass and Bioenergy, 2010, 34 (5), pp.602-609. 10.1016/j.biombioe.2010.01.002 . hal-00477323

\section{HAL Id: hal-00477323 \\ https://hal.science/hal-00477323}

Submitted on 28 Apr 2010

HAL is a multi-disciplinary open access archive for the deposit and dissemination of scientific research documents, whether they are published or not. The documents may come from teaching and research institutions in France or abroad, or from public or private research centers.
L'archive ouverte pluridisciplinaire HAL, est destinée au dépôt et à la diffusion de documents scientifiques de niveau recherche, publiés ou non, émanant des établissements d'enseignement et de recherche français ou étrangers, des laboratoires publics ou privés. 

pilot kiln

\author{
REPELLIN Vincent(1), GOVIN Alexandre(1)*, ROLLAND Mathieu( ${ }^{(2)}$, GUYONNET René(1)
}

(1) Ecole Nationale Supérieure des Mines de Saint Etienne, Centre SPIN - Département PMMC ; LPMG -UMR CNRS 5148, 158 Cours Fauriel - 42023 Saint-Étienne Cedex 2, France

(2) IFP-Lyon, Direction Expérimentation Procédés, Rond-Point de l'échangeur de Solaize, 69390 Solaize, France

\begin{abstract}
:
Beech and spruce chips were torrefied in a batch rotating pilot kiln. For each torrefaction the temperature curve of the moving chips bed was recorded. The anhydrous weight loss (AWL) of each torrefaction was measured. Effect of torrefaction temperature and duration on the AWL was studied. In order to optimise short time torrefaction, models that can estimate the AWL from the chips temperature curve are required. Three phenomenological models were successfully applied. They all gave good correlations between experimental and calculated AWL. These three models can be employed to optimise industrial torrefaction. However, the more complex they are, the more difficult it is to understand their physical meaning. It is thus preferable to use simple model for the industrial control of torrefaction.
\end{abstract}

Keywords:

Heat treatment ; Torrefaction; Wood chips ; Reaction kinetics ; Wood fuels

\title{
I. Introduction
}

Biomass, in particular wood and forest residues, is the largest source of renewable material and energy. Nowadays the use of wood as building material is promoted. Wood can store large amounts of carbon and its processing induces less $\mathrm{CO}_{2}$ emissions than other materials [1] and [2]. Facing the decrease of fossil fuels resources, it becomes also crucial to enhance the use of biomass as a source of energy. To use biomass as a source of energy, different ways are considered such as direct combustion, co-firing in power plants, production of biomass based motor fuels. For example, diesel can be made from biomass by Fischer-Tropsch synthesis. Fischer-Tropsch synthesis requires a preliminary gasification. Gasification produces syngas $\left(\mathrm{H}_{2}\right.$ and $\left.\mathrm{CO}\right)$ by heating biomass particles at temperatures between $800^{\circ} \mathrm{C}$ and $1000^{\circ} \mathrm{C}$. In order to perform gasification at high yields, wood must be reduced to fine powder. However wood has viscous-elastic and plastic behaviours. Grinding wood requires a lot of energy, because a lot of energy is dissipated before failure [3] and [4].

Torrefaction is a heat treatment at low temperature, which may improve wood grindability [5]. Contrary to natural wood, torrefied wood has a brittle behaviour and a decreased mechanical strength. A lot of energy necessary for powdering wood may thus be saved [5]. Moreover torrefaction increases the carbon content of wood. Its energy content is consequently enhanced [6] and [7]. Heat treatments decrease biomass moisture content and hygroscopicity [8], [9] and [10]. The advantages provided by torrefaction may also be useful for co-firing, or pellets manufacturing [11] and [12]. The torrefaction is energy-consuming, and therefore the energy balance "torrefaction - grinding" is reduced. However, the energy balance between energy gain made by grinding, the increase in the heat value of wood and energy consumption for torrefaction seems favourable [11], [12] and [13].

* Auteur à qui la correspondance devait être adressée : govin@emse.fr 
In a more detailed way, torrefaction is a heat treatment of ligno-cellulosic material carried out at temperatures inferior to $300^{\circ} \mathrm{C}$. Torrefaction can be carried out under different gaseous atmospheres. Nitrogen or hot gases released during the thermal treatment are employed most of time. It avoids exothermic reactions that are likely to occur in presence of oxygen. When exothermic reactions take place, a fast and uncontrolled increase in temperature of the material occurs. However, chemical reactions involved during torrefaction as well as final properties of the material depend strongly on the temperature of the wood. To control the torrefaction process, it is consequently necessary to monitor the temperature of the material, and not only the temperature of the kiln that can be quite different. Kiln temperature is not adequate to estimate the advancement of torrefaction. To monitor correctly material temperature, a thermocouple has to be dived into the wood chips bed.

From the chemical point of view, wood is composed of three main structure constituents: cellulose (35 to 40 weight \%), hemicelluloses (20 to 30 weight \%) and lignin (20 to 30 weight $\%)$. It contains also 1 to 4 weight \% of extractives compounds [14]. During torrefaction, slow pyrolysis prevails: wood is thermally decomposed at a slow rate [15] and [16]. This decomposition leads to an anhydrous weight loss (AWL) of the wood. AWL is representative for physical-chemical transformations of wood. AWL matches to the advancement of the torrefaction reaction. At temperatures below $300^{\circ} \mathrm{C}$, the main products of wood decomposition are water, carbon dioxide, carbon monoxide, formic acid, acetic acid and furfural. Many studies have shown that these products correspond mainly to hemicelluloses decomposition. Nevertheless, lignin and cellulose undergo also some decomposition, in particular when the temperature goes over $250^{\circ} \mathrm{C}$ [17], [18] and [19].

Properties of torrefied biomass depend on the AWL. Hence, controlling the torrefaction process means to control precisely the AWL of the material. It requires a model to estimate the AWL from the temperature record of the material. The purpose of this study is to examine different models that can be used as tools to predict the AWL. A large number of torrefactions were carried out. AWLs of each torrefaction were measured. The temperature of wood chips was recorded during torrefaction runs. According to these temperature records, different models were employed to predict the AWL. Parameters of each model were fitted, and the relevance of these models was examined.

\section{Materials and Methods}

\section{II.1. Torrefaction kiln}

A pilot kiln designed at the Ecole des Mines de Saint Etienne was used to carry out torrefactions. It was an airtight rotating batch kiln with a volume of 30 litres. The kiln consisted of a cylindrical chamber made of stainless steel. When wood chips were introduced into the kiln, the chamber was closed to become airtight with outside. It rotated on itself in order to homogenize the wood charge. The whole (chamber and wood) was heated by electrical resistors located just below the rotating cage and regulated by a controller.

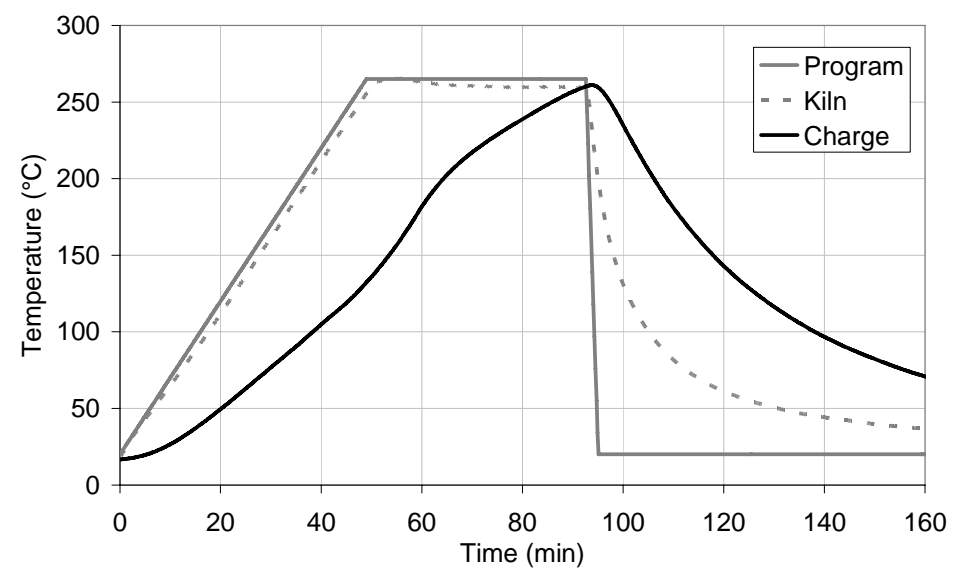

Figure 1: Typical curves of the temperatures recorded during a torrefaction run. 
Biomass \& Bioenergy, 2010, 34(5), 602-609, doi : 10.1016/j.biombioe.2010.01.002

Torrefactions were carried out under nitrogen flow $(6 \mathrm{~L} / \mathrm{min})$. The temperature of the kiln was measured on the outer surface of the metal chamber of the reactor and used for control. The temperature of the material was measured in the moving bed of wood chips by the way of a thermocouple. Wood chips had to have a volume at least of 6 litres, to ensure a correct surrounding of the thermocouple. Figure 1 presents typical curves of the temperatures recorded during a torrefaction run.

\section{II.2. Samples}

Forty three torrefactions were carried out on wood chips. Two kinds of wood species were used: spruce and beech. These species were chosen as typical European softwood and hardwood. The samples had been equilibrated at ambient temperature and humidity at least for 3 months. Table 1 summarizes the properties of the wood chip: wood density, chips bulk density, average particle sizes, moisture content and mass employed for one torrefaction. Owing to wood density and chips sizes, bulk density of beech chips was much higher than bulk density of spruce chips. Consequently, to ensure that the volume of chips was large enough to surround correctly the thermocouple, the mass of beech chips had to be 1.5 times higher than the mass of spruce chips.

Table 1: Properties of the wood chips.

\begin{tabular}{|c|c|c|c|c|c|c|c|}
\hline \multirow{2}{*}{$\begin{array}{c}\text { Wood } \\
\text { Species }\end{array}$} & \multirow{2}{*}{$\begin{array}{l}\text { Specific } \\
\text { gravity } \\
\left(\mathrm{kg} / \mathrm{m}^{3}\right)\end{array}$} & \multirow{2}{*}{$\begin{array}{c}\text { Chips bulk } \\
\text { density } \\
\left(\mathrm{kg} / \mathrm{m}^{3}\right)\end{array}$} & \multicolumn{3}{|c|}{ Average particles sizes (mm) } & \multirow{2}{*}{$\begin{array}{l}\text { Moisture } \\
\text { content } \\
\text { (\%) }\end{array}$} & \multirow{2}{*}{$\begin{array}{l}\text { Mass of } \\
\text { one batch } \\
\text { (kg) }\end{array}$} \\
\hline & & & thickness & width & length & & \\
\hline Spruce & 450 & 155 & 2 to 5 & 5 to 2 & 15 & 11 & 1 \\
\hline Beech & 680 & 285 & 1 to 2 & 10 to 15 & 15 to 30 & 11,8 & 1,5 \\
\hline
\end{tabular}

II.3. Torrefaction parameters

For given chips size, species and gaseous atmosphere, the AWL depends only on two parameters: torrefaction temperature and duration. [Table 2] and [Table 3] present the parameters of the forty three torrefactions carried out for this study. The nomenclature of each torrefaction is composed of three parts. The first part is the wood chips specie: $\mathrm{S}$ for spruce and B for beech. The second one is torrefaction temperature, and the third one is torrefaction duration. For example, a run labelled B-240-20, is a torrefaction of beech wood chips carried out at $240^{\circ} \mathrm{C}$ during 20 min.

Table 2: Torrefaction of spruce chips: nomenclature and parameters.

\begin{tabular}{cccc}
\hline Name & $\begin{array}{c}\text { Torrefaction } \\
\text { temperature }\left({ }^{\circ} \mathrm{C}\right)\end{array}$ & $\begin{array}{c}\text { Torrefaction } \\
\text { duration (min) }\end{array}$ & Number of runs \\
S-160-5 & 160 & 5 & 2 \\
S-200-5 & 200 & 5 & 2 \\
S-220-5 & 220 & 5 & 2 \\
S-240-5 & 240 & 5 & 2 \\
S-260-5 & 260 & 5 & 2 \\
S-280-5 & 280 & 5 & 3 \\
S-300-5 & 300 & 5 & 3 \\
\hline
\end{tabular}

Once torrefaction temperature and duration were chosen, the kiln temperature was programmed. At first, it was increased at a rate of $5^{\circ} \mathrm{C} / \mathrm{min}$ until the torrefaction temperature. Then it was kept at torrefaction temperature until the temperature of wood chips reached torrefaction temperature. Then, kiln and chips temperatures were kept constant for the torrefaction duration. Once this duration was completed, the kiln was cooled by removing its thermal insulation.

As can be seen on Figure 1, there is a large difference between the temperature of the outside of the envelope from the kiln (temperature used for control purpose) and the temperature of the charge. Torrefaction parameters as defined previously are consequently a rough estimation of the temperature curve of chips. Hence, torrefaction parameters do not allow a precise prediction of the AWL. Any model for predicting the AWL must rely on the 
Biomass \& Bioenergy, 2010, 34(5), 602-609, doi : 10.1016/j.biombioe.2010.01.002

temperature curve of wood chips. In this work, three different models were applied to the chips temperature curves.

Table 3: Torrefaction of beech chips: nomenclature and parameters.

\begin{tabular}{cccc}
\hline Name & $\begin{array}{c}\text { Torrefaction } \\
\text { temperature }\left({ }^{\circ} \mathrm{C}\right)\end{array}$ & $\begin{array}{c}\text { Torrefaction } \\
\text { duration (min) }\end{array}$ & $\begin{array}{c}\text { Number of } \\
\text { runs }\end{array}$ \\
$\mathrm{B}-180-5$ & 180 & 5 & 2 \\
$\mathrm{~B}-200-5$ & 200 & 5 & 2 \\
$\mathrm{~B}-220-5$ & 220 & 5 & 2 \\
$\mathrm{~B}-240-5$ & 240 & 5 & 2 \\
$\mathrm{~B}-260-5$ & 260 & 5 & 2 \\
$\mathrm{~B}-280-5$ & 280 & 5 & 2 \\
$\mathrm{~B}-220-20$ & 220 & 20 & 2 \\
$\mathrm{~B}-240-20$ & 240 & 20 & 2 \\
$\mathrm{~B}-260-20$ & 260 & 20 & 2 \\
$\mathrm{~B}-220-40$ & 220 & 40 & 2 \\
$\mathrm{~B}-240-40$ & 240 & 40 & 2 \\
$\mathrm{~B}-260-40$ & 260 & 60 & 2 \\
$\mathrm{~B}-220-60$ & 220 & 60 & 1 \\
$\mathrm{~B}-240-60$ & 240 & 60 & 1 \\
$\mathrm{~B}-260-60$ & 260 & 60 & 1 \\
\hline
\end{tabular}

II.4. Anhydrous weight loss measurement

The moisture content (MC) of the natural chips was first measured before each torrefaction. Few grams were taken and weighed $\left(\mathrm{m}_{\mathrm{i}}\right)$. Then it was oven dried at $103 \mathrm{C}$ for $24 \mathrm{~h}$, cooled in desiccators and weighed again in its anhydrous state $\left(\mathrm{m}_{\mathrm{o}}\right)$. The MC in percent was calculated as follow:

$\mathrm{MC}=\frac{\left(\mathrm{m}_{\mathrm{i}}-\mathrm{m}_{0}\right) \times 100}{\mathrm{~m}_{0}}$

The mass of the batch of natural wood $\left(\mathrm{m}_{\text {nat }}\right)$ was weighted. The mass of anhydrous natural wood $\left(\mathrm{m}_{\text {nato\%}}\right)$ was then calculated in function of the MC:

$\mathrm{m}_{\text {nat } \%}=\frac{100 \times \mathrm{m}_{\text {nat }}}{(\mathrm{MC}+100)}$

The mass of anhydrous torrefied wood $\left(\mathrm{m}_{\mathrm{toro}}\right)$ was weighted directly after torrefaction. Finally, the AWL was estimated as follow:

$$
\mathrm{AWL}=\frac{\mathrm{m}_{\mathrm{nat} 0 \%}-\mathrm{m}_{\mathrm{tor} 0 \%}}{\mathrm{~m}_{\text {nat } 0 \%}} \times 100
$$

\section{II.5. Thermal analysis measurements}

Thermo gravimetric analyses (TGA) were carried out on beech wood. Isotherms were done at $220^{\circ} \mathrm{C}, 240^{\circ} \mathrm{C}$ and $260^{\circ} \mathrm{C}$. The samples were made of $10 \mathrm{mg}$ of beech wood powder. They were obtained by grinding and sieving beech wood between 150 and $212 \mu \mathrm{m}$. Before experiment, the samples were stored at room temperature in ambient humidity. The device was a thermobalance Netsch TG 209. The temperature program began by a ramp from $30^{\circ} \mathrm{C}$ to $150^{\circ} \mathrm{C}$ at $30^{\circ} \mathrm{C} / \mathrm{min}$. It was followed by an isotherm at $150^{\circ} \mathrm{C}$ for 20 min to dry the sample until its anhydrous state. Mass reference was set to zero at this point. A ramp was carried out at $99^{\circ} \mathrm{C} / \mathrm{min}$ from $150^{\circ} \mathrm{C}$ to the isotherm temperature: $220^{\circ} \mathrm{C}, 240^{\circ} \mathrm{C}$ or $260^{\circ} \mathrm{C}$. The isotherm temperature duration was 80 min. This procedure allowed calculating the anhydrous weight loss of the samples in function of time. The results were compared to the AWL obtained by torrefaction of beech wood. 


\section{Experimental results and discussion}

\section{III.1. Temperature curves and thermal transfer}

A large difference was measured between kiln temperature curve and wood chips temperature curve (Figure 1). Temperature difference can be explained by several effects: the oven design (heat transfer area, thermal inertia, nitrogen flow ...), charge properties (species, moisture content, mass, chips sizes) or thermocouple position. For the same reasons, torrefaction reproducibility can be difficult and each experiment was carried out twice ([Table 2] and [Table 3]). Consistently, torrefaction temperatures were reached faster for spruce than for beech. For S-260-5 and B-260-5, it took in 85 minutes for spruce and 105 minutes for beech to reach torrefaction temperature. This difference can be mainly attributed to the mass of chips and then quantity of water to be evaporated, which is 1.5 times higher for beech. Therefore, more energy is needed to evaporate the water content of beech. This takes longer. Therefore, the wood itself reaches the desired temperature later. Particle size and species may also play a role. Hence, chips temperature curve depends on the properties of the chips feedstock (specie, particle sizes and mass). Though, the chips temperature curve will determine the AWL. Beech and spruce charges do not have the same mass and particle sizes. Thus, AWLs of spruce and beech are not comparable.

A second level of thermal transfer limitation may happen within a chip. Typical characteristics times of wood chips were calculated. They represent the time taken for the centre of a wood chip to reach a temperature imposed at the surface of this chip. At $200^{\circ} \mathrm{C}$ these characteristic times were found equal to 8 seconds for beech and 11 seconds for spruce. This is in agreement with the thermal conductivities of beech and spruce which are around 0.16 and $0.11 \mathrm{~W} / \mathrm{mK}$, respectively [20]. These characteristics times were short regarding treatment duration and rate of temperature increase. Thus, thermal transfer within wood chips was neglected in this study.

\section{III.2. Anhydrous weight loss}

Figure 2 presents the AWL of spruce and beech in function of the torrefaction temperature, for treatment durations of 5 minutes. Large scattering between AWL values is visible, for example on S-280-5. It confirms the difficulty to carry out reproducible torrefaction on the ground of torrefaction parameters. From $160^{\circ} \mathrm{C}$ to $300^{\circ} \mathrm{C}$, the AWL of spruce varies from $\mathrm{o} \%$ to $30 \%$. Heat treatment of spruce at $160^{\circ} \mathrm{C}$ did not lead to any AWL. The AWL increased to $1 \%$ for spruce at $220^{\circ} \mathrm{C}$. From $180^{\circ} \mathrm{C}$ to $280^{\circ} \mathrm{C}$, the AWL of beech varies also from $0 \%$ to $30 \%$. It was inferior to $0.5 \%$ for $\mathrm{B}-180-5$ and $\mathrm{B}-200-5$. It increased to $5 \%$ at $220^{\circ} \mathrm{C}$. For the same torrefaction temperature, AWL of beech wood is superior to the AWL of spruce.

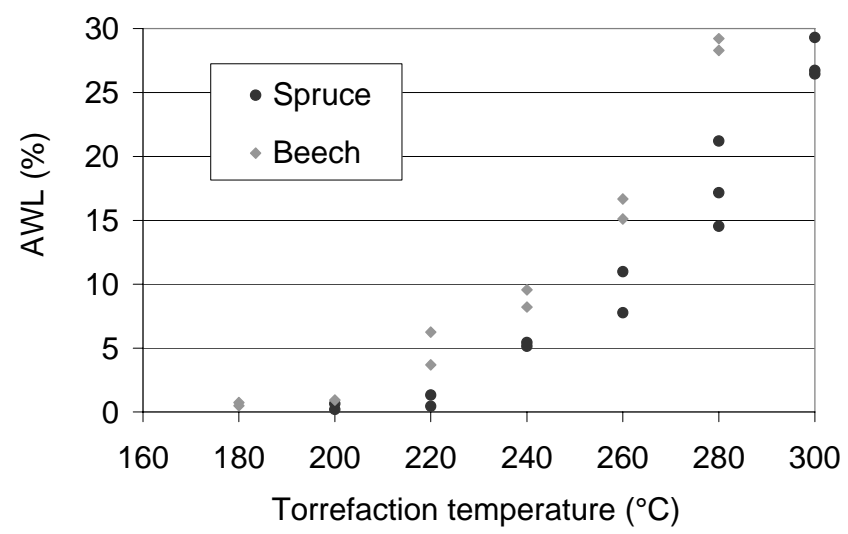

Figure 2: AWL obtained in function of the temperature of torrefaction of beech and spruce wood chips. Samples are kept 5 minutes at torrefaction temperature.

This may be due to heat transfer and to chemical composition of the two species. As discussed previously heat transfer between the reactor envelope and the wood chips is longer for beech than for spruce. In other words, beech is exposed to high temperature for a longer time than spruce. In the temperature range of torrefaction, thermal decomposition has an effect mainly 
Biomass \& Bioenergy, 2010, 34(5), 602-609, doi : 10.1016/j.biombioe.2010.01.002

on hemicelluloses. Among hemicelluloses, xylans thermal decomposition occurs at lower temperature than other hemicelluloses decomposition [16], [17] and [18]. Beech contains 27.5 $\%$ of xylans, whereas spruce contains only $8.6 \%$ of xylans [21]. The AWL is expected to be higher for beech than for spruce, as observed experimentally.

Figure 3 presents the AWL of beech wood as a function of torrefaction duration, at $220^{\circ} \mathrm{C}$, $240^{\circ} \mathrm{C}$ and $260^{\circ} \mathrm{C}$. The AWL curves can be separated in two stages. The first one corresponds to a rapid increase in AWL and the second one matches with a slow increase. For example, during the first step at $260^{\circ} \mathrm{C}$, the AWL increases quickly during 20 minutes up to $22.7 \%$ (B260-20), while during the second step, it only increases to $25.6 \%$ (B-260-60) in 40 additional minutes. The first step duration last longer when temperature decreases. Despite the different analytical conditions, similar results were obtained by TGA (Figure 4). The advantage of the TGA is its ability to continuously monitor the mass evolution of wood. On the isotherms at $220^{\circ} \mathrm{C}, 240^{\circ} \mathrm{C}$ and $260^{\circ} \mathrm{C}$, the AWL increases rapidly at first. It increases slowly in a second step. Thus, the major part of the AWL occurs in the first stage, at the beginning of torrefaction. As visible on Figure 3, this first stage is completed within 20 minutes. Over 20 minutes, the AWL increases very slowly. For duration superior to 20 minutes, the AWL depends almost only on torrefaction temperature. However, short time treatments are the most interesting from the industrial and economical point of view. For torrefaction of durations inferior to 20 minutes, the entire temperature curve of the charge must be taken into account. For example, torrefaction B-260-5 involved a temperature ramp between $200^{\circ} \mathrm{C}$ and $260^{\circ} \mathrm{C}$. This temperature ramp has a significant influence on the AWL. A model is thus necessary to evaluate the AWL from the temperature curve of the charge. Such a model would allow an accurate control of the torrefaction process.

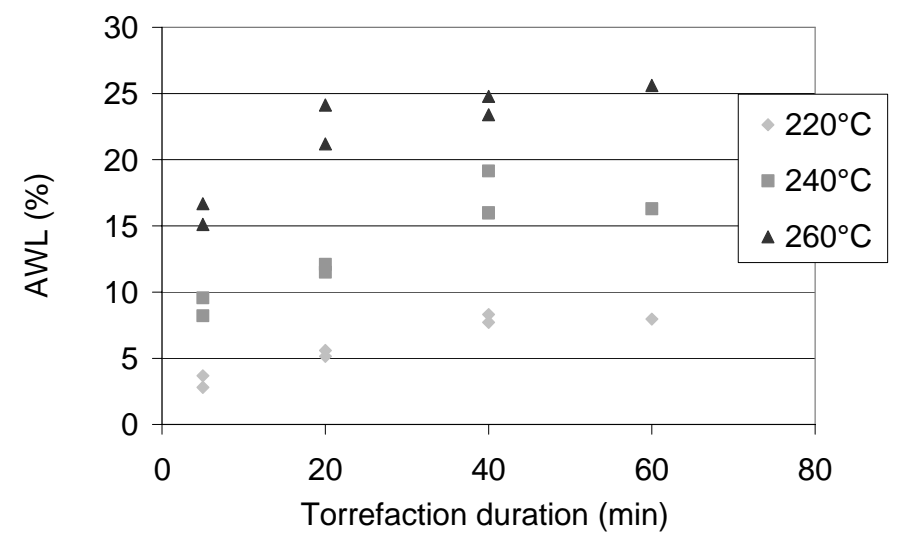

Figure 3: AWL in function of the duration of torrefaction of beech wood chips.

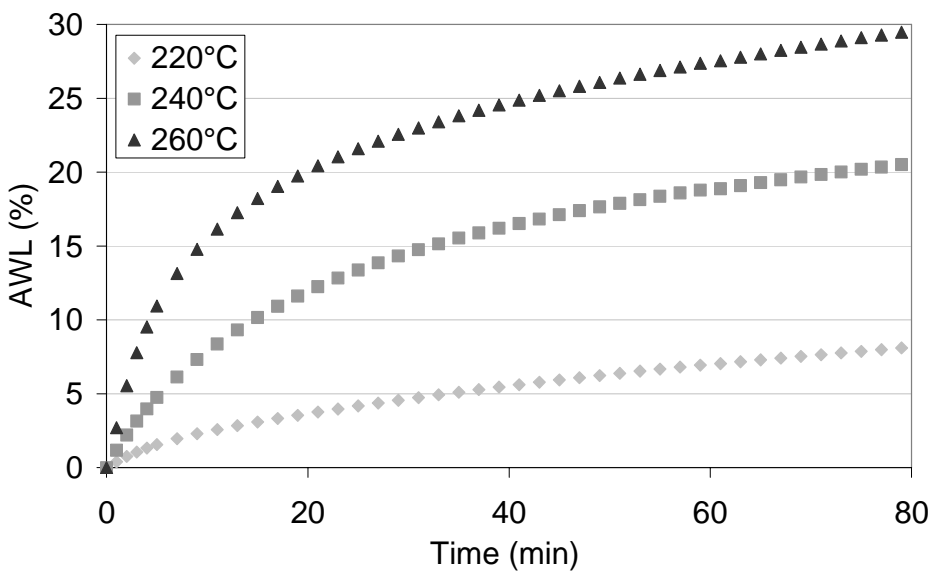

Figure 4: Isothermal thermo-gravimetric analysis of beech wood powder 


\section{Modelling torrefaction}

Wood thermal degradation is a set of reactions that involves many different chemical compounds. Wood constituents are complex, and there are numerous torrefaction products [17] and [22]. Torrefaction models are approximations of the real phenomena and are necessarily simplified. However, such models are required as tools for controlling torrefaction process. Since transfer phenomena can be neglected, it is supposed that torrefaction is kinetically controlled. Three kinetic models are examined, here after referred to as "simple", "Di Blasi - Lanzetta" and "Rousset" models. In these models, kinetics of all reactions is assumed to follow an Arrhenius law with two parameters: activation energy and kinetic constant. For the three models, these parameters were adjusted in order to fit, the calculated AWL, to our experimental AWL, using the least square method (Figure 5). The parameters used for the fitting was: Iterations: $10^{4}$, Precision: $10^{-6}$, Convergence: $10^{-6}$.

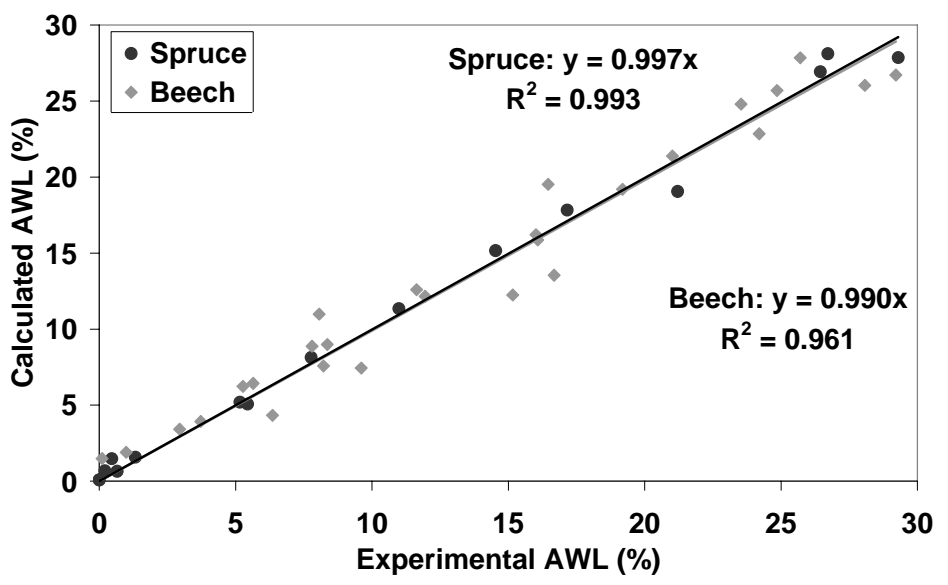

Figure 5: Correlation between experimental AWL and calculated AWL obtained with simple model, for spruce and beech.

\section{IV.1. Simple model}

The simple model is a one equation global model of wood decomposition, which seems to be relevant at low temperatures [23].

Wood $\rightarrow$ Char + Volatiles $\left(\mathrm{k}_{\mathrm{oM}}, \mathrm{E}_{\mathrm{AM} 1}\right)$

This simple model has only two parameters $\left(\mathrm{k}_{\mathrm{OM}_{1}}\right.$ and $\left.\mathrm{E}_{\mathrm{AM}_{1}}\right)$. Wood, char and volatiles are not well defined chemical compounds. Nevertheless, they are used as 'pseudo' chemical compounds in Equation (4). On the one hand, the 'pseudo' molar mass of volatiles (MV) and char (MC) are not known. On the other hand, the experimental yields in volatiles and chars must be taken into account. For this purpose, an additional parameter, $\mathrm{f}$, must be introduced in the model and optimised. $f$ is defined as the ratio of pseudo molar mass of volatiles on pseudo molar mass of char (Equation (5)).

$\mathrm{f}=\frac{\mathrm{M}_{\mathrm{v}}}{\mathrm{M}_{\mathrm{C}}}$

Thermal decomposition of wood at low temperature involves reactions such as decarboxylation, decomposition of O-methyl groups, and hydrolysis of O-acetyl groups [16]. As volatiles are of low molecular weight, and char molecules are polymer chains of high molecular weight, $\mathrm{f}$ is expected to be lower than one. Activation energy of spruce mentioned in literature is $92.0 \mathrm{~kJ} \mathrm{~mol}^{-1}$ [24]. This value was determined, by the authors, assuming a first order reaction. Since this value had been determined accurately with dynamic TGA measurements by Gronli et al. [25], we preferred not to adjust the activation energy. It is supposed that the composition of the ligno-cellulosic material of beech is close to the one of 
Biomass \& Bioenergy, 2010, 34(5), 602-609, doi : 10.1016/j.biombioe.2010.01.002

spruce. This assumption implies that the thermal decomposition of these two species is almost similar. That is why we employed the same value of the activation energy for the two species. The initial value of $\mathrm{k}_{\mathrm{OM} 1}$ was $1.58 \times 10^{6} \mathrm{~s}^{-1}$ [25]. $\mathrm{f}$ was set at o.1. Then, adjustment of the values of $\mathrm{k}_{\mathrm{OM}}$ and $\mathrm{f}$ was performed. A good correlation was obtained between the calculated and the experimental AWL (Figure 5). Table 4 shows the slopes and the coefficients of correlations of linear regressions. After adjustment, $\mathrm{f}$ was equal to 0.71 for spruce and 0.47 for beech. These values of $\mathrm{f}$ are indeed lower than one although an interpretation of theses values is difficult. The kinetic constants $\left(\mathrm{k}_{\mathrm{oM}}\right)$ were $1.02 \times 10^{5} \mathrm{~s}^{-1}$ and $2.88 \times 10^{5} \mathrm{~s}^{-1}$ respectively for spruce and beech. This is in good agreement with the known fact that hardwoods (beech) have a higher reactivity than softwoods (spruce). Variations of wood, char and volatiles mass for torrefaction B-260-5 are presented on Figure 6 This model does not take into account the numerous reactions involved in heat treatment at low temperature [22]. However, it provides a good estimation of the AWL.

Table 4: Results of the three models.

\begin{tabular}{clccc}
\hline Species & \multicolumn{1}{c}{$\begin{array}{c}\text { Linear } \\
\text { regression }\end{array}$} & Simple & $\begin{array}{c}\text { Di Blazi- } \\
\text { Lanzetta }\end{array}$ & Rousset \\
& Slope & 0.997 & 0.996 & 0.998 \\
Spruce & $\mathrm{R}^{2}$ & 0.993 & 0.987 & 0.963 \\
& Slope & 0.990 & 0.993 & 0.990 \\
& $\mathrm{R}^{2}$ & 0.961 & 0.986 & 0.970 \\
\hline
\end{tabular}

B-260-5

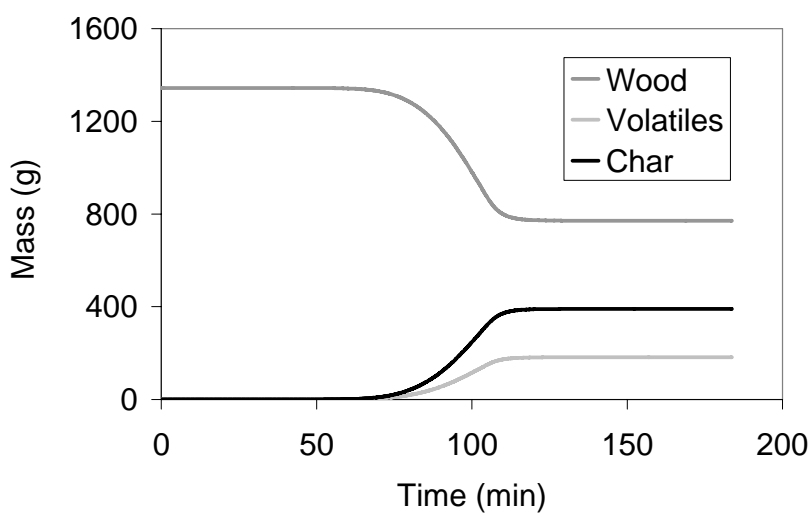

Figure 6: Evolution of wood, char and volatiles according to the simple model.

IV.2. Di Blazi-Lanzetta model

The second model (Equation (6)) was proposed by Di Blazi and Lanzetta [26]

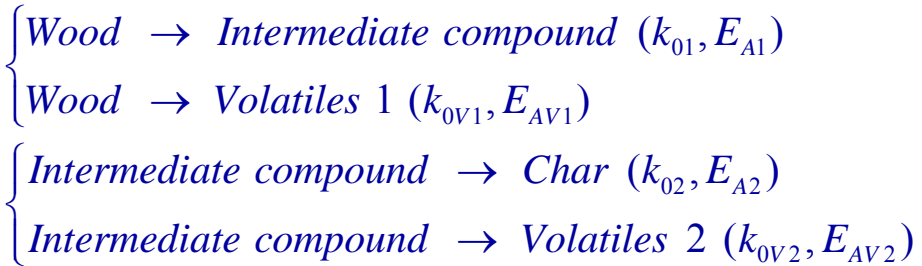

This model was originally developed to describe the thermal decomposition of xylan. In the temperature range of torrefaction, the hemicelluloses are the most degraded constituents of wood. Xylan is the most thermally degraded hemicellulose. Its thermal decomposition occurs in the temperature range of torrefaction. When applied to biomass, this model gave good results for thermal decomposition of straw [27] and willow [28]. This model assumes that in a first step, wood decomposes in volatiles and intermediate compound. In a second step, the intermediate compound decomposes in volatiles and char. The four reactions of this model are considered independent one from each other. The model requires 8 independents parameters (Table 5). These parameters were accurately determined in isothermal conditions 
Biomass \& Bioenergy, 2010, 34(5), 602-609, doi : 10.1016/j.biombioe.2010.01.002

with a thermobalance by Prins et al. [28] for willow. As for the simple model, activation energy values were set as found by Prins et al. Thus 4 parameters were adjusted: $\mathrm{k}_{01}, \mathrm{k}_{\mathrm{oV}}, \mathrm{k}_{\mathrm{o} 2}$, and $\mathrm{k}_{\mathrm{ov} 2}$. Their values are presented on Table 5 , and variations of wood, char, intermediate product and volatiles mass are presented on Figure 7 for torrefaction B-260-5. A good correlation with experimental AWL was obtained (Table 4). For beech, the correlation is slightly better than with the simple model. The good agreement between experimental and calculated AWL could be due to the taking into account of the intermediate compound. The existence of this intermediate compound relies on accurate experimental observation [26]. It could match to the remaining polymer chains, after reactions such as decarboxylation or decomposition of O-methyl groups. In this model, char is produced from the intermediate product at high temperatures. This is experimentally realistic. As torrefaction temperature increases, the carbon content increases, and wood look more and more like char. For B-2805 , the model gives a char content of $7 \%$ in weight of the torrefied wood. Nevertheless, physical interpretation of this model is somewhat difficult. In particular, the direct and independent transformation of wood into volatiles and intermediate product is difficult to justify. For example, hydrolysis of O-acetyl groups of xylan (main hemicellulose of hardwood) produces acetic acid and a remaining polymer chain. These two products are not formed independently. The same remark applies to the transformation of the intermediate product into volatiles and char.

Table 5: Kinetic parameters of Di Blasi- Lanzetta model.

\begin{tabular}{ccc}
\hline Parameter & Spruce & Beech \\
$\mathrm{k}_{\mathrm{O} 1}\left(\mathrm{~s}^{-1}\right)$ & $2.4710^{4}$ & $2.4810^{4}$ \\
$\mathrm{E}_{\mathrm{A} 1}\left(\mathrm{kJmol}^{-1}\right)$ & 76.0 & 76.0 \\
$\mathrm{k}_{\mathrm{oV} 1}\left(\mathrm{~s}^{-1}\right)$ & $1.9510^{7}$ & $3.9410^{7}$ \\
$\mathrm{E}_{\mathrm{AV} 1}\left(\mathrm{kJmol}^{-1}\right)$ & 11.4 & 11.4 \\
$\mathrm{k}_{\mathrm{O} 2}\left(\mathrm{~s}^{-1}\right)$ & $1.1010^{10}$ & $1.1010^{10}$ \\
$\mathrm{E}_{\mathrm{A} 2}\left(\mathrm{kJmol}^{-1}\right)$ & 151.7 & 151.7 \\
$\mathrm{k}_{\mathrm{OV} 2}\left(\mathrm{~s}^{-1}\right)$ & $4.1010^{6}$ & $4.1210^{6}$ \\
$\mathrm{E}_{\mathrm{AV} 2}\left(\mathrm{kJmol}^{-1}\right)$ & 11.4 & 11.4 \\
\hline
\end{tabular}

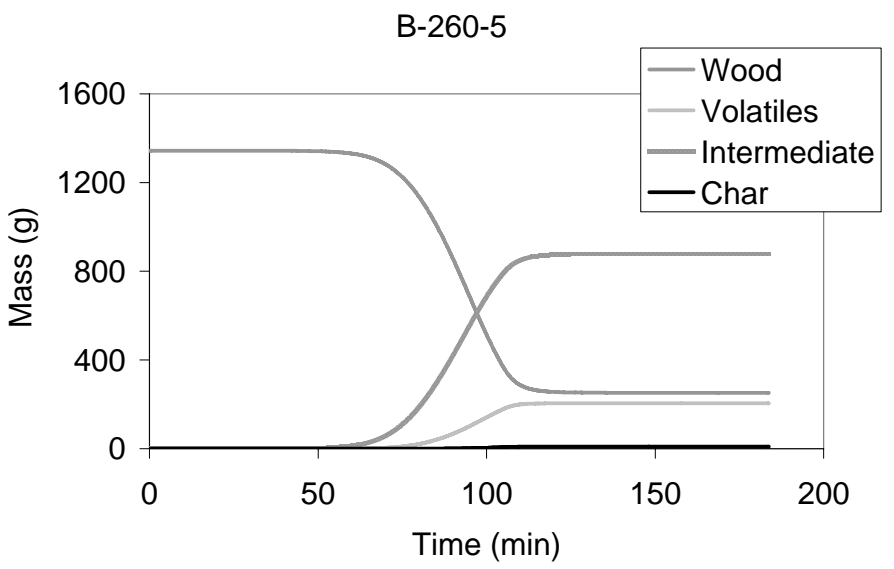

Figure 7: Evolution of wood, volatiles, intermediate compound and char according to the Di blaziLanzetta model.

\section{IV.3. Rousset model}

The third model (Equation (7)) was developed by Rousset et al. after an extensive literature review [24]. It assumes that wood thermal decomposition is a superposition of the thermal decomposition of its main constituents (lignin, cellulose, and hemicelluloses) in proportion to their content in wood. Lignin decomposes into char and volatiles in a simple decomposition path. Cellulose decomposes independently in tar and in char plus volatiles, according to the 
Broido-Shafizadeh model. Hemicelluloses decompose according to the Di Blasi-Lanzetta model, with creation of an intermediate product (B).

As well as with the simple model, it was necessary to define ratios of molar mass of volatiles to molar mass of char, both for lignin $\left(f_{\mathrm{L}}\right)$ and cellulose $\left(\mathrm{f}_{\mathrm{CC}}\right)$ decomposition. The initial values of the kinetic constants and the activation energy were chosen according to Rousset et al. [24] As for the previous models, activation energies were kept constant, and only the values of kinetic constants were adjusted $\left(\mathrm{k}_{\mathrm{OLC}}, \mathrm{f}_{\mathrm{L}}, \mathrm{k}_{\mathrm{OCT}}, \mathrm{k}_{\mathrm{OCC}}, \mathrm{f}_{\mathrm{CC}}, \mathrm{k}_{\mathrm{OHB}}, \mathrm{k}_{\mathrm{OHV}}, \mathrm{k}_{\mathrm{OBC}}, \mathrm{k}_{\mathrm{OBV}}\right.$ ). Direct adjustment of these nine parameters gave non physical values: slightly negative values of $\mathrm{f}_{\mathrm{L}}$ and $\mathrm{k}_{\mathrm{OBV}}$ indicated that these reactions may not be occurring. $\mathrm{f}_{\mathrm{CC}}$ reached 35 , to be compared with a value of 3.6 used by Rousset.

$$
\begin{aligned}
& \text { Lignins } \rightarrow \text { Char + Volatiles } 1\left(\mathrm{k}_{0 \mathrm{LC}}, \mathrm{E}_{\mathrm{ALC}}, \mathrm{f}_{\mathrm{L}}\right) \\
& \left\{\begin{array}{l}
\text { Cellulose } \rightarrow \text { Tar }\left(k_{0 C T}, E_{A C T}\right) \\
\text { Cellulose } \rightarrow \text { Char }+ \text { Volatiles } 2\left(k_{0 C C}, E_{A C C}, f_{C C}\right)
\end{array}\right. \\
& \left\{\begin{array}{l}
\text { Hemicelluloses } \rightarrow B\left(k_{0 H B}, E_{A H B}\right) \\
\text { Hemicelluloses } \rightarrow \text { Volatiles } 3\left(k_{0 H V 3}, E_{A H V 3}\right) \\
B \rightarrow \text { Char }\left(k_{0 B C}, E_{A B C}\right) \\
B \rightarrow \text { Volatiles } 4\left(k_{0 B V 4}, E_{A B V 4}\right)
\end{array}\right.
\end{aligned}
$$

In a second approach, volatiles products of lignin decomposition and decomposition of B into volatiles were neglected ( $f_{\mathrm{L}}$ and $\mathrm{k}_{\mathrm{OBV}}$ set to o). $\mathrm{B}$ decomposes only into char. $\mathrm{f}_{\mathrm{CC}}$ was set at the value proposed by Rousset: 3.6. With these assumptions, the modified Rousset model can be rewritten as follow (Equation (8)):

$$
\begin{aligned}
& \text { Lignins } \rightarrow \text { Char }\left(\mathrm{k}_{0 \mathrm{LC}}, \mathrm{E}_{\mathrm{ALC}}\right) \\
& \left\{\begin{array}{l}
\text { Cellulose } \rightarrow \text { Tar }\left(k_{0 C T}, E_{A C T}\right) \\
\text { Cellulose } \rightarrow \text { Char }+ \text { Volatiles } 2\left(k_{0 C C}, E_{A C C}, f_{C C}\right)
\end{array}\right. \\
& \left\{\begin{array}{l}
\text { Hemicelluloses } \rightarrow B\left(k_{0 H B}, E_{A H B}\right) \\
\text { Hemicelluloses } \rightarrow \text { Volatiles } 3\left(k_{0 H V 3}, E_{A H V 3}\right) \\
B \rightarrow \text { Char }\left(k_{0 B C}, E_{A B C}\right)
\end{array}\right.
\end{aligned}
$$

Based on these new hypotheses a new adjustment was carried out on the 6 remaining parameters. A good correlation between experimental and calculated AWL was found (Table 4). Evolution of wood, char, volatiles and intermediate compounds are presented on Figure 8. The corresponding values of the parameters are presented on Table 6. Adjustment influenced mainly hemicelluloses parameters. It is well known that in the temperature range of torrefaction, hemicelluloses decompose more than lignin or cellulose [18]. The Rousset model takes well into account this experimental observation. As visible on Figure 9, the Rousset model predicts that lignin and cellulose hardly react. On the contrary, half of the amount of hemicelluloses is decomposed, causing the overall AWL of wood.

However, the adjusted values of $k_{\mathrm{OHB}}$ and $\mathrm{k}_{\mathrm{OBC}}$ are much higher for spruce than for beech (Table 6), which would indicate that spruce reacts more than beech. This result is in contradiction with experimental observation: beech has a higher reactivity than spruce. Moreover, the hypotheses made on $\mathrm{f}_{\mathrm{L}}, \mathrm{k}_{\mathrm{OBV}}$ and $\mathrm{f}_{\mathrm{CC}}$, question the chosen mechanisms of constituents decomposition and the hypothesis of superposition. Thermal decomposition of isolated wood constituents is indeed different from their thermal decomposition in native wood [29] and [30]. The presence of minerals may also catalyse wood constituents degradation in an unpredictable ways [31].

Wood constituents decomposition occurs generally in three steps; visible by differential thermal analysis [32] and [33]. However, these three steps do not match to isolated lignin, hemicelluloses and cellulose decompositions. Grioui et al., Órfão et al., introduced 'pseudo' component of wood, each pseudo component corresponding to a step of thermal 
Biomass \& Bioenergy, 2010, 34(5), 602-609, doi : 10.1016/j.biombioe.2010.01.002

decomposition of wood. These authors calculated kinetics constants of the three pseudo components [32] and [33]. Their model of wood decomposition is a superposition of the three pseudo components decomposition. They obtained a good correlation between their calculated and experimental values of AWL obtained in TGA. However, our set of data was not sufficient to apply this model.

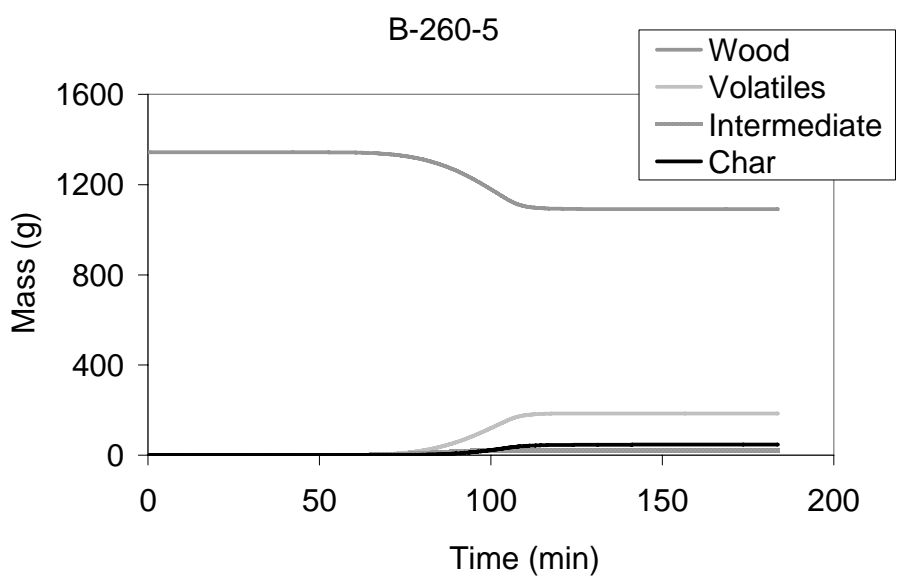

Figure 8: Evolution of wood, volatiles, intermediate compound and char according to the Rousset model.

Table 6: Kinetic parameters of Rousset's model.

\begin{tabular}{cccc}
\hline Parameter & Rousset's & Spruce & Beech \\
& parameters & & \\
$\mathrm{k}_{\mathrm{OLC}}\left(\mathrm{s}^{-1}\right)$ & $2.7710^{7}$ & $2.7710^{7}$ & $2.7710^{7}$ \\
$\mathrm{E}_{\mathrm{ALC}}\left(\mathrm{kJmol}^{-1}\right)$ & 124.3 & 124.3 & 124.3 \\
$\mathrm{f}_{\mathrm{L}}$ & 0.1 & $\mathrm{O}$ & $\mathrm{O}$ \\
$\mathrm{k}_{\mathrm{OCT}}\left(\mathrm{s}^{-1}\right)$ & $2.5110^{9}$ & $2.5110^{9}$ & $2.5110^{9}$ \\
$\mathrm{E}_{\mathrm{ACC}}\left(\mathrm{kJmol}^{-1}\right)$ & 179.0 & 179.0 & 179.0 \\
$\mathrm{k}_{\mathrm{OCC}}\left(\mathrm{s}^{-1}\right)$ & $6.6610^{15}$ & $6.6610^{15}$ & $6.6610^{15}$ \\
$\mathrm{E}_{\mathrm{ACC}}\left(\mathrm{kJmol}^{-1}\right)$ & 217.5 & 217.5 & 217.5 \\
$\mathrm{f}_{\mathrm{CC}}$ & 3.6 & 3.6 & 3.6 \\
$\mathrm{k}_{\mathrm{OHB}}\left(\mathrm{s}^{-1}\right)$ & $1.7410^{4}$ & $1.3910^{3}$ & $3.1810^{2}$ \\
$\mathrm{E}_{\mathrm{AHB}}\left(\mathrm{kJmol}^{-1}\right)$ & 66.1 & 66.1 & 66.1 \\
$\mathrm{k}_{\mathrm{OHV}}\left(\mathrm{s}^{-1}\right)$ & $3.3110^{6}$ & $3.810^{5}$ & $3.6910^{5}$ \\
$\mathrm{E}_{\mathrm{AHV}}\left(\mathrm{kJmol}^{-1}\right)$ & 91.4 & 91.4 & 91.4 \\
$\mathrm{k}_{\mathrm{OBC}}\left(\mathrm{s}^{-1}\right)$ & $3.4310^{2}$ & $1.0510^{4}$ & $4.0910^{2}$ \\
$\mathrm{E}_{\mathrm{ABC}}\left(\mathrm{kJmol}^{-1}\right)$ & 56.3 & 56.3 & 56.3 \\
$\mathrm{k}_{\mathrm{OBV}}\left(\mathrm{s}^{-1}\right)$ & $5.8710^{1}$ & 0 & 0 \\
$\mathrm{E}_{\mathrm{ABV}}\left(\mathrm{kJmol}^{-1}\right)$ & 52.6 & 52.6 & 52.6 \\
\hline
\end{tabular}

For all three models examined in this work, it was possible to find a set of kinetic parameters that led to a good agreement between modelled and experimental AWL. Nevertheless these models predict quite different reactivity for beech and spruce. For the simple model and the Di Blazy-Lanzetta model, beech has a higher reactivity than spruce. According to the Rousset model, spruce has a higher reactivity than beech. These differences might allow discriminating between these three models. 


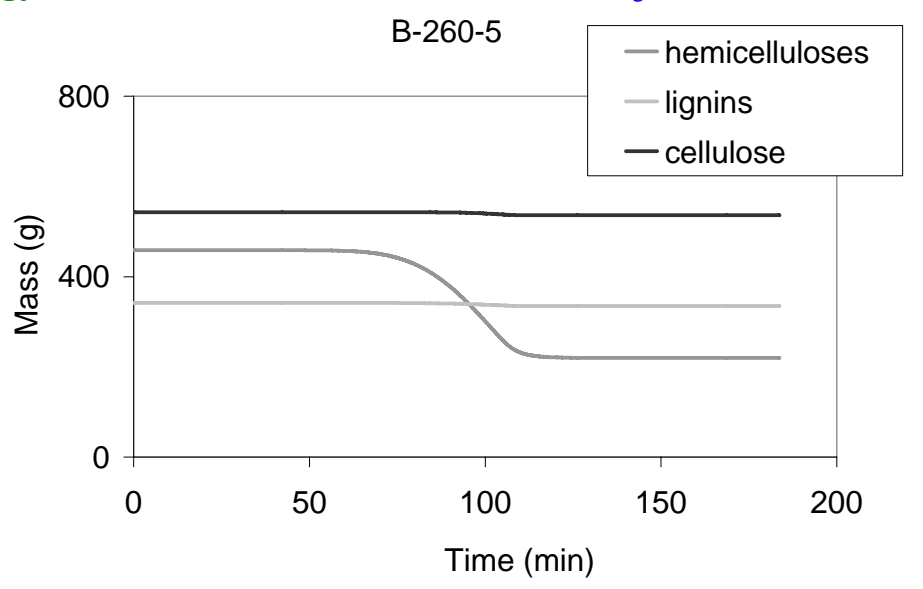

Figure 9: Evolution of hemicelluloses, lignin and cellulose for B-260-5 according to the Rousset model.

\section{Conclusion}

In this study, forty three torrefactions were carried out. Beech and spruce chips were treated in a batch rotating pilot kiln. For each torrefaction the temperature curve of the moving chips bed was recorded. The AWL of torrefaction was measured. Effect of torrefaction temperature and duration on the AWL was studied. AWLs between $0 \%$ and 30\% were obtained, depending on the parameters. The results showed that the AWL occurred at the beginning of torrefaction (within 20 minutes). In order to optimise short time torrefaction, models that can estimate the AWL from the chips temperature curve are required. As thermal decomposition of wood involves many reactions, these models are global. They are more phenomenological models than kinetic models. Three models were successfully applied. They all gave good correlations between experimental and calculated AWL. These three models can be employed to optimise industrial torrefaction. However, the more complex they are, the more difficult it is to understand their physical meaning. It is thus preferable to use simple model for the design of industrial torrefaction kilns.

\section{References}

[1] P. Börjesson, L. Gustavsson, Greenhouse gas balance in building construction: wood versus concrete from life-cycle and forest land-use perspectives, Energy Policy 28 (2000) 575-588.

[2] A.H. Buchanan, S.B. Levine, Wood-based building materials and atmospheric carbon emissions, Environ. Sci. Policy 2 (1999) 427-437.

[3] L.S. Esteban, J.E. Carrasco, Evaluation of different strategies for pulverisation of forest biomasses, Powder Technol. 166 (2006) 139-151.

[4] G. Schubert, S. Bernotat, Comminution of non brittle materials, Int. J. Miner. Process. 74 (2004) 19-30.

[5] P.C.A. Bergman, J.H.A. Kiel, Torrefaction for biomass upgrading, In: Sjunnesson, L., Carrasco, J.E., Helm P., Grassi A. (Eds), Proc. $14^{\text {th }}$ European Biomass Conference, Paris, France, 2005, pp.206-209.

[6] J. Bourgois, R. Guyonnet, Characterisation and analysis of torrefied wood, Wood Sci. Technol. 22 (1988) 143-155.

[7] J. Bourgois, M.-C. Bartholin, R. Guyonnet, Thermal treatment of wood: analysis of the obtain product, Wood Sci. Technol. 23 (1989) 303-310.

[8] D.P. Kamden, A. Pizzi, A. Jermanaud, Durability of heat-treated wood, Holz Roh. Werkst. 60 (2002) 1-6.

[9] S. Mouras, P. Girard, P. Rousset, P. Permadi, D. Dirol, G. Labat, Propriétés physiques de bois peu durables soumis à un traitement de pyrolyse ménagée, Ann. For. Sci. 59 (2002) 317-326. 
Biomass \& Bioenergy, 2010, 34(5), 602-609, doi : 10.1016/j.biombioe.2010.01.002

[10] P. Niemz, P. Bekhta, Effect of high temperature on the change in color, dimensional stability and mechanical properties of spruce wood, Holzforschung 57 (2003) 539-546.

[11] P.C.A. Bergman, A.R. Boersma, R.W.R. Zwart, J.H.A. Kiel, Torrefaction for biomass cofiring in existing coal-fired power stations; Biocoal, ECN report (2005), ENC-C--05-013.

[12] P.C.A. Bergman, Combined torrefaction and pelletisation: the TOP process, ECN report (2005), ECN-C--05-073.

[13] M.J. Prins, K.J. Ptasinski, F.J.J.G. Janssen, More efficient biomass gasification via torrefaction, Energy 31 (2006) 3458-3470

[14] D. Fengel, G. Wegener, Wood chemistry, Ultrastructure, Reactions, Walter De Gruyter, Berlin, 1983.

[15] F.L. Browne, Theories of the combustion of wood and its control, US Forest Product Lab., (1958), Report 2136.

[16] W.F. Degroot, W.P. Pan, D. Rahman, G.N. Richards, First chemical events in pyrolysis of wood, J. Anal. Appl. Pyrol. 13 (1988) 221-231.

[17] J.J. Weiland, R. Guyonnet, R. Gibert, Analysis of controlled wood burning by combination of thermogravimetric analysis, differential scanning calorimetry and Fourier transform infrared spectroscopy, J. Therm. Anal. Calorim. 51 (1998) 265-274.

[18] V. Repellin, R. Guyonnet, Evaluation of heat-treated wood swelling by differential scanning calorimetry in relation to chemical composition, Holzforschung 59 (2005) 2834 .

[19] T. Elder, Pyrolysis of wood, In Wood and Cellulosic Chemistry, D.N.-S. Hon and N. Shiraishi Editors, Marcel Dekker, New York 1991, pp. 665-699.

[20] J. Sell, F. Kropf, Propriétés et caractéristiques des essences de bois, Lignum Editors, Union Suisse en fafeur du bois, Le Mont 1990.

[21] E. Sjöström, Wood chemistry: fundamentals and applications, $2^{\text {nd }}$ ed. Academic Press, San Diego 1993.

[22] O. Faix, I. Fortmann, J. Bremer, D. Meier, Thermal degradation of wood products: gas chromatographic separation and mass spectrometric characterization of polysaccharides derived products, Holz Roh. Werkst. 49 (1991) 213-219.

[23] P. Permadi, Optimisation du traitement thermique appliqué au bois d'œuvre pour l'amélioration des propriétés des espèces non durables, Report of Ph-D Thesis, UTC, Compiègne, France, 2000, pp.107-11.

[24] P. Rousset, I. Turner, A. Donnot, P. Perré, The choice of a low-temperature pyrolysis model at the microscopic level for use in a macroscopic formulation, Ann. For. Sci. 63 (2006) 213-229.

[25] M.G. Grønli, Holst Sørensen L, Hustad JE. In: Rousset P. Choix et validation expérimentale d'un modèle de pyrolyse pour le bois traité par haute température: de la microparticule au bois massif. Report of Ph-D Thesis, Université Henry Poincaré, Nancy, France, 2004, pp 49.

[26] C. Di Blasi, M. Lanzetta, Intrinsic kinetics of isothermal xylan degradation in inert atmosphere, J. Anal. Appl. Pyrol. 40 (1997) 287-303.

[27] M. Lanzetta, C. Di Blasi, Pyrolysis kinetics of wheat and corn straw, J. Anal. Appl. Pyrol. 44 (1998) 181-192.

[28] J.M. Prins, K.J. Ptasinski, F.J.J.G. Janssen, Torrefaction of wood part 1, Weight loss kinetics, J. Anal. Appl. Pyrol. 77 (2006) 28-34.

[29] E. Wozniac, Evolution de la texture poreuse du bois de hêtre au cours de sa pyrolyse contribution aux phénomènes de transport et d'adsorption dans les matériaux ligneux. Report of Ph-D Thesis, Université de Haute Alsace, Mulhouse, France, 1982, pp. 29-37.

[30] M.-C. Bartholin, H. Besset, J. Bourgois, R. Guyonnet, Le bois torréfié : étude du mécanisme réactionnel en vue d'une meilleure spécification du produit, Ecole des Mines de Saint-Etienne Report (1986) AFME 13-5, pp. 47-69.

[31] G. Várhegyi, M.J. Jr. Antal, E. Jakab, P. Szabó, Kinetic modelling of biomass pyrolysis, J. Anal. Appl. Pyrol. 42 (1997) 73-87 
Biomass \& Bioenergy, 2010, 34(5), 602-609, doi : 10.1016/j.biombioe.2010.01.002

[32] N. Grioui, K. Halouani, A. Zoulalian and F. Halouani, Thermogravimetric analysis and kinetics modeling of isothermal carbonisation of olive wood in inert atmosphere, Thermochim Acta 404 (2006), pp. 23-30.

[33] J.J.M. Órfão, F.J.A. Antunes and J.L. Figueiredo, Pyrolysis kinetics of lignocellulosic materials - three independent reactions model, Fuel 78 (1999), pp. 349-358. 